\title{
BÊ̂NH GAN CHUYỂN HOÁ Ở TRẺ EM
}

\section{TÓM TẮT}

Đặt vấn đề: Bệnh gan chuyển hoá ở trẻ em khác với bệnh chuyển hóa ở người trưởng thành, đa số các bệnh trong nhóm này có nguyên nhân di truyền. Tuy biểu hiện kiểu hình từ nhỏ song nếu không được phát hiên và điều tri bệnh gan chuyển hoá ở trẻ em có thể sẽ có những đợt diễn biến cấp tính với nguy cơ tử vong hoăc tiến triển thành bệnh gan mạn tính ở người trưởng thành với những hậu quả xơ gan, tăng áp lực tĩnh mach cửa, bênh lý gan giai đoạn cuối... Cho tới nay, hiện còn chứa có nhiều nghiên cứu về bệnh gan chuyển hoá nói chung và bênh gan chuyển hoá ở trẻ em nói riêng. Mục tiêu: "Nhận xét đặc điểm lâm sàng và cân lâm sàng các bểnh gan do rối loan chuyển hoá ở trẻ em". Đối tượng và phương pháp nguyên cứu: Nghiên cứu mô tả. Thu thập các triệu chứng lâm sàng và cận lâm sàng trên nhóm bệnh nhân có bệnh gan chuyển hoá tại bệnh viện Nhi Trung ương trong thời gian 2008-2019. Kết quả: Có 478 bệnh nhân có bệnh lý gan do rối loạn chuyển hóa di truyền. Chiếm nhiều nhất là NICCD với 186 trường hợp (38,9\%),với tuổi chẩn đoán trung bình 3,2 $\pm 1,6$ tháng tháng với các triệu chứng thường gặp là vàng da ứ mật, suy chức năng gan và khuôn mặt Chubby face. 112 trường hợp Wilson có đô tuổi phát hiên trung bình $11 \pm 4,8$ tuổi chiếm tỷ lệ 23,4\% với kiểu hình bệnh gan mạn tính và suy gan tối cấp. Trong nhóm nghiên cứu có 64 bệnh nhân (chiếm tỷ lệ $13,5 \%$ ) được chẩn đoán xác đinh Glycogenose bằng tiêu chuẩn chẩn đoán mô bệnh học, 38 bệnh nhân Alagille $(7,9 \%)$ hội chứng PFIC có 14 ca bênh $(2,9 \%)$, 2 ca bệnh có hội chứng ARC $(2,4 \%)$ và 3 ca thiếu hụt anpha1antitrypsin (AAT). Có 49 trường hợp $(10,4 \%)$ thuộc nhóm RLCHK gồm các bệnh nhân Rotor; rối loạn chuyển hoá acid mật, Galactosemia, Tyrosinemia, DGOUK... mỗi bênh chỉ phát hiện 1 bệnh nhân và 44 trường hợp có tổn thương gan kèm theo các triêu chứng của bệnh rối loạn chuyển hóa song không xác đinh đước nguyên nhẩnrất có ý nghĩa trong tiếp cân chẩn đoán. Kết luận: Các bệnh rối loạn chuyển hoá là nhóm nguyên nhân quan trọng gây các bệnh gan mạn tính ở trẻ em. Phát hiên, điều trị sớm và quản lý nhóm các bệnh nhân này không chỉ có ý nghĩa cứu sống bênh nhi mà còn hạn chế các hâu quả lâu dài của bệnh khi bước vào tuổi trưởng thành, tư vấn di truyền nhằm han chế sư lan truyền gen bênh

Tư khoá: bệnh gan chuyển hoá, PFIC, Alagille, ARC, Wilson, Glycogenose

\section{SUMMARY}

METABOLIC LIVER DISEASE IN CHILDREN

*Bệnh viện Nhi Trung ương

Chịu trách nhiệm chính: Nguyễn Phạm Anh Hoa

Email: dranhhoa@gmail.com

Ngày nhận bài: $22 \cdot 10.2020$

Ngày phản biên khoa hoc: 26.11 .2020

Ngày duyệt bài: 10.12 .2020

\section{Nguyễn Phạm Anh Hoa*}

Background: Metabolic liver disease in children is not similar that in adults, most of them are caused by genetic disoder. Most of symtoms of metabolic liver disease in children can present from childhood. In the case the diseases are not diagnosed and managed, they may progress to chronic liver disease in adults with consequences of cirrhosis, portal hypertension, end-stage liver disease or have acute episodes with the risk of death.... Up to now, we only have a few studies on metabolic liver disease in children. Aims: " Review of clinical and subclinical characteristics of metabolic liver diseases in children". Materials and methods: Descriptive study on group of metabolic liver disease patients at Vietnam National children's hospital from 2008-2019. Results: There are 478 metabolic liver disease. NICCD group has highest rate with 186 cases (38.9\%), average age 3,2 - 1,6 months with symtoms cholestasis, liver failure and Chubby face. 112 Wilson cases with an average age of 11 - 4.8 years, accounting for $23.4 \%$ of all group with many diverse phenotypes and progression. There are 64 patients (accounting for $13.5 \%$ ) were diagnosed with Glycogenose by histopathological criteria, 38 Alagille patients $(7.9 \%)$ who has not only cholestasis but also congenital heart disease, abnormal spine and kidney defects... PFIC syndrome has 14 cases (2.9\%), 12 cases with ARC syndrome $(2.5 \%), 3$ cases anpha1antitrypsin deficiency(AAT) $0,6 \%$. There were 49 cases (10.4\%) included Rotor; bile acid metabolism disorder, Galactosemia, Tyrosinemia, DGOUK... (only 1 patient for each disease) and group of patients who have had abnormal liver test with evidence of a nonclassified metabolic disorder. Conclusion: Metabolic liver disease are complicated group, which can cause acute episode or chronic liver disease in children. Early detection and management of this group in th childhood not only cure patients but also limit the long-term consequences of the chronic liver disease in adulthood and genetic counseling

Key words: Metabolic liver disease, PFIC, Alagille, ARC, Wilson, Glycogenose

\section{I. ĐẶT VẤN ĐỀ}

Gan là cơ quan chuyển hoá chính của cơ thể với hệ thống enzym và các protein vận chuyển, đảm nhận phần lớn chức năng chuyển hoá của cơ thể. Hệ thống các enzym và protein, cơ chất tham gia vào các quá trình chuyển hoá này được mã hoá bởi các gen riêng biệt. Đột biến ở các gen mã hoá sẽ gây thiếu cơ chất, protein vận chuyển hoăc các enzym xúc tác không đủ chức năng dẫn tới hậu quả rối loạn chuyển hoá... Các bất thường trong các quá trình chuyển hoá do gan đảm nhận gây bệnh gan chuyển hoá với các kiểu hình lâm sàng đa dạng. Bệnh gan chuyển hoá ở trẻ em khác với bệnh chuyển hóa ở người trưởng thành như béo phì, gan nhiễm mõ, tăng 
triglyceride...Bệnh có thể biểu hiện kiểu hình ở bất kỳ độ tuổi nào, song thường xuất hiện ở trẻ nhỏ do giai đoạn này cơ thể có nhu câuu trao đổi chất cao. Một số bệnh khởi phát các triệu chứng đầu tiên ngay trong những ngày đầu sau sinh, ngay khi cơ thể trẻ phải tự chuyển hoá mà không còn sự hỗ trợ của tuần hoàn mẹ như giai đoạn trẻ còn trong tử cung. Hầu hết các bệnh gan chuyển hoá đều thuộc nhóm bệnh hiếm, đa số các bệnh này đều thuộc nhóm bệnh di truyền gen lặn. Tỷ lệ mang đột biến và tỷ lệ mắc của các bệnh đều có tính chất đặc trưng theo từng vùng địa lý và chủng tộc. Tuy biểu hiện kiểu hình từ thời kỳ tuổi nhỏ song nếu không được phát hiện và điều trị thì bệnh gan chuyển hoá ở trẻ em có thể sẽ có những đợt diễn biến cấp tính với nguy cơ tử vong hoặc tiến triển thành bệnh gan mạn tính ở người trưởng thành với những hậu quả xơ gan, tăng áp lực tĩnh mạch cửa, bệnh lý gan giai đoạn cuối...Cho tới nay, chưa có nhiều nghiên cứu về bệnh gan chuyển hoá ở trẻ em. Nghiên cứu này tập trung vào 1 số bệnh chuyển hoá gây tổn thương gan thường gặp ở chuyên khoa Gan mật như Wilson, NICCD, Glycogenose, Alagille, ARC (Arthrogryposis-renal dysfunctioncholestasis), PFIC (progressive familial intrahepatic cholestasis), thiếu hụt alpha 1 antitrypsin (AAT) và một số rối loạn chuyển hoá khác ít gặp và không xác định khác (RLCH khác) với mục tiêu: "Nhận xét đặc điểm lâm sàng và cận lâm sàng một số bệnh gan chuyển hoá ở trẻ em".

\section{II. ĐỐI TƯƠ'NG VÀ PHƯƠNG PHÁP NGHIÊN CỨU}

2. Nghiên cứu mô tả. Thu thập các bệnh nhân có bệnh lý gan do nguyên nhân rối loạn chuyển hoá tại Bệnh viện Nhi Trung ương trong thời gian 2008-2019. Thu thập các đặc điểm lâm sàng và cận lâm sàng của các bệnh nhân đã có đủ tiêu chuẩn chẩn đoán xác định (mang đột biến gen SLC25A13 đồng hợp tử hoặc dị hợp tử kép đối với NICCD; đủ 4 điểm theo tiêu chuẩn Leipzig 2001 cho bệnh Wislon, chẩn đoán mô bệnh học đối với Glycogenose...) tại thời điểm nhập viện đâuu tiên theo mẫu nghiên cứu thống nhất và xử lý số liệu bằng phần mềm thống kê y học.

\section{KẾT QUẢ NGHIÊN CỨU}

\section{1. Đặc điểm chung về nhóm nghiên cứu}

Có 478 bệnh nhân có bênh lý gan do rối loạn chuyển hóa đủ tiêu chuẩn nghiên cứu, gồm 275 trẻ nam ( 57,5\%) và 203 trẻ nữ $(42,5 \%)$, không có sự khác biệt có ý nghĩa thống kê về tỷ lệ nam nữ trong nhóm nghiên cứu

\section{Các nguyên nhân gây bệnh gan} chuyển hoá ở trẻ em

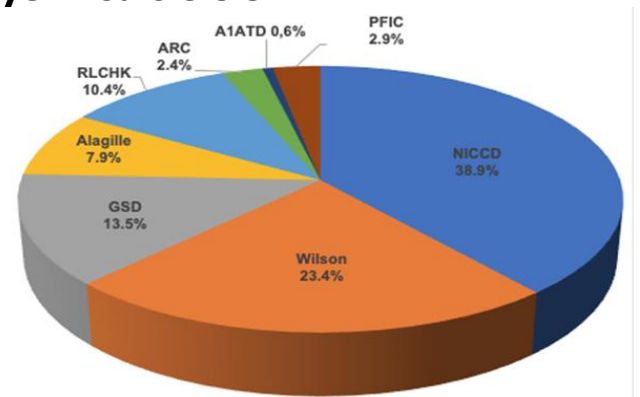

Biểu đồ 1: Nguyên nhân gây bệnh gan chuyển hoá ở trẻ em

GSD: Glycogenose; AAT: Thiếu hụt Alpha1 antitrypsin; PFIC: progressive familial intrahepatic cholestasis; ARC: Arthrogryposisrenaldysfunction-cholestasis

NICCD: Neonatal intrahepatic cholestasis; RLCHK: Rối loạn chuyển hoá không phân loại và 1 số nguyên nhân hiếm gặp ( Rotor; rối loạn chuyển hoá acid mật, Galactosemia, Tyrosinemia

3. Đặc điểm lâm sàng và cận lâm sàng ở trẻ có bệnh gan chuyển hoá

Bảng 1: Các triệu chứng lầm sàng thường gặp ở trẻ có bệnh gan chuyển hoá

\begin{tabular}{|c|c|c|c|c|c|c|c|}
\hline Bệnh & Gan to & Lách to & Vàng da & Dị tật & $\begin{array}{c}\text { Bất thường } \\
\text { hình thể }\end{array}$ & $\begin{array}{c}\text { Chậm } \\
\text { PTTC(1) }\end{array}$ & RLTH(2) $^{(2)}$ \\
\hline NICCD & $142(76,3 \%)$ & $28(15,1 \%)$ & $152(81,7 \%)$ & $5(2,7 \%)$ & $142(76,3 \%)$ & $32(17,2 \%)$ & $125(67,2 \%)$ \\
\hline Wilson & $18(16,1 \%)$ & $21(18,8 \%)$ & $8(7,1 \%)$ & $1(0,9 \%)$ & $0 \%$ & $0 \%$ & $0 \%$ \\
\hline GSD & $64(100 \%)$ & $0 \%$ & $0 \%$ & $0 \%$ & $38(59,4 \%)$ & $22(34,4 \%)$ & $37(57,8 \%)$ \\
\hline Alagille & $29(76,3 \%)$ & $18(47,4 \%)$ & $31(81,6 \%)$ & $38(100 \%)$ & $30(78,9 \%)$ & $26(68,4 \%)$ & $25(65,8 \%)$ \\
\hline RLCHK & $30(61,2 \%)$ & $28(53,8 \%)$ & $28(53,8 \%)$ & $41(78,8 \%)$ & $8(15,4 \%)$ & $2(3,8 \%)$ & $12(23,1 \%)$ \\
\hline ARC & $3(25 \%)$ & $2(16,7 \%)$ & $12(100 \%)$ & $12(100 \%)$ & $100 \%$ & $11(91,7 \%)$ & $0 \%$ \\
\hline AAT & $1(33,3 \%)$ & $0 \%$ & $3(100 \%)$ & $0 \%$ & $0 \%$ & $0 \%$ & $0 \%$ \\
\hline PFIC & $12(85,7 \%)$ & $6(42,9 \%)$ & $14(100 \%)$ & $3(21,4 \%)$ & $0 \%$ & $12(85,7 \%)$ & $6(42,8 \%)$ \\
\hline Tống ${ }^{(3)}$ & $62,6 \%$ & $21,5 \%$ & $51.3 \%$ & $20.9 \%$ & $48.1 \%$ & $21,9 \%$ & $42.9 \%$ \\
\hline
\end{tabular}

Chậm phát triển thể chất, ${ }^{(2)}$ Rối loạn tiêu hoá ${ }^{(3)}$ Tỷ lệ \% trong nhóm bệnh gan chuyển hoá 
VIETNAM MEDICAL JOURNAL N¹ - JANUARY - 2021

\begin{tabular}{|c|c|c|c|c|c|c|c|}
\hline $\begin{array}{l}\text { Cận lâm } \\
\text { sàng }\end{array}$ & $\begin{array}{c}\text { Tăng } \\
\text { Bilirubin }\end{array}$ & $\mathbf{R L Đ M}^{(1)}$ & $\begin{array}{c}\text { Giảm } \\
\text { Albumin }\end{array}$ & Tăng AST & Tăng ALT & Tăng ALP & Tăng GGT \\
\hline NICCD & $\begin{array}{c}161 \\
(86,6 \%)\end{array}$ & $164(88,2 \%)$ & $136(73,1 \%)$ & $179(92,2 \%)$ & $162(87,1 \%)$ & $\begin{array}{c}165 \\
(88,7 \%)\end{array}$ & $\begin{array}{c}80 \\
(43,1 \%)\end{array}$ \\
\hline Wilson & $8(7,1 \%)$ & $52(46,4 \%)$ & $34(30,3 \%)$ & $54(48,2 \%)$ & $62(55,4 \%)$ & $2(1,8 \%)$ & $1(0,9 \%)$ \\
\hline GSD & $0 \%$ & $0 \%$ & $0 \%$ & & & $5(7,8 \%)$ & $2(3,1 \%)$ \\
\hline Alagille & $32(84,2 \%)$ & $12(31,6 \%)$ & $5(13,2 \%)$ & $38(100 \%)$ & $21(55,3 \%)$ & $\begin{array}{c}31 \\
(81,6 \%)\end{array}$ & $\begin{array}{c}34 \\
(89,5 \%)\end{array}$ \\
\hline RLCHK & $33(67,3 \%)$ & $38(73,1 \%)$ & $29(55,8 \%)$ & $38(77,6 \%)$ & $46(88,5 \%)$ & $\begin{array}{c}11 \\
(21,2 \%)\end{array}$ & $\begin{array}{c}32 \\
(61,5 \%)\end{array}$ \\
\hline ARC & $12(100 \%)$ & $2(16$ & $3(25 \%)$ & & & $8(66,7 \%)$ & $6(50 \%)$ \\
\hline PFIC & $14(100 \%)$ & $5(35,1 \%)$ & $1(7,1 \%)$ & $14(100 \%)$ & $14(100 \%)$ & $14(100 \%)$ & $8(57,1 \%)$ \\
\hline AAT & $3(100 \%)$ & $0 \%$ & $0 \%$ & $3(100 \%)$ & $3(100 \%)$ & $0 \%$ & $0 \%$ \\
\hline Tổng (2) & $263(55 \%)$ & $273(57,1 \%)$ & $208(43,5 \%)$ & $395(82,6 \%)$ & $375(78,5 \%)$ & $\begin{array}{c}236 \\
(49,4 \%)\end{array}$ & $\begin{array}{c}163 \\
(34,1 \%)\end{array}$ \\
\hline
\end{tabular}

${ }^{(1)}$ Rối loạn đông máu, ${ }^{(2)}$ tỷ lệ \% trong nhóm bệnh gan chuyển hoá

Các thay đổi chức năng gan thường gặp nhất ở các bệnh gan chuyển hoá gồm tăng AST $(82,6 \%)$, $\operatorname{ALT}(78,5 \%)$, tăng Bilirubin(55\%) và RLĐM(57,1\%).

\begin{tabular}{|c|c|c|c|c|c|c|}
\hline $\begin{array}{l}\text { Cận lâm } \\
\text { sàng }\end{array}$ & Tăng Lactac & $\begin{array}{c}\text { Tăng } \\
\text { Cholesterol }\end{array}$ & $\begin{array}{c}\text { Tăng } \\
\text { Triglycerid }\end{array}$ & Hạ Glucose & Tăng NH3 & Tăng AFP \\
\hline NICCD & $112(60,2 \%)$ & $78(41,9 \%)$ & $68(36,6 \%)$ & $114(61,3 \%)$ & $145(77,9 \%)$ & $\begin{array}{c}125 \\
(67,2 \%)\end{array}$ \\
\hline Wilson & $0 \%$ & $0 \%$ & $0 \%$ & $0 \%$ & $0 \%$ & 0 \\
\hline GSD & $41(64,1 \%)$ & $38(59,4 \%)$ & $42(65,6 \%)$ & $42(65,6 \%)$ & $0 \%$ & $5(7,8 \%)$ \\
\hline Alagille & $0 \%$ & $9(23,7 \%)$ & $3(7,9 \%)$ & $2(5,2 \%)$ & $0 \%$ & 0 \\
\hline RLCHK & $48(92,3$ & $39(75 \%)$ & $24(46,2 \%)$ & $38(73,1 \%)$ & $22(42,3 \%)$ & $6(11,5 \%)$ \\
\hline ARC & $5(41,7 \%)$ & $1(8,3 \%)$ & $2(16,7 \%)$ & $0 \%$ & $0 \%$ & 0 \\
\hline PFIC & $1(7,1 \%)$ & $5(35,7 \%)$ & $8(57,1 \%)$ & $0 \%$ & $0 \%$ & $1(7,1 \%)$ \\
\hline AAT & $0 \%$ & $0 \%$ & $0 \%$ & $0 \%$ & $0 \%$ & $0 \%$ \\
\hline Tổng(1) & $207(43,3 \%)$ & $170(35,6 \%)$ & $147(30,8 \%)$ & $196(41,0 \%)$ & 169 (34\%) & $\begin{array}{c}137 \\
(28,7 \%)\end{array}$ \\
\hline
\end{tabular}

Tỷ lệ \% trong toàn nhóm bệnh gan chuyển hoá

Tăng Lactat gặp nhiều nhất ở bệnh nhân NICCD (60,2\%), GSD (64,1\%), RLCHK (92,3\%). Tăng Cholesterol và Triglycerid gặp nhiêu nhất ở các bệnh nhân GSD (59,4\% và 65,6\%), RLCHK, NICCD. Bệnh nhân NICCD, GSD và nhóm RLCHK thường có hạ Glucose máu. Tăng NH3 và AFP gặp với tỷ lệ cao nhất ở các bệnh nhân NICCD, RLCHK.

\section{BÀN LUẬN}

Những năm trước đây, do điêu kiện tiếp cận chẩn đoán còn hạn chế nên các bệnh lý gan mật trẻ em, đặc biệt là các bệnh liên quan tới chuyển hóa di truyền còn chưa được quan tâm nghiên cứu. Việc chẩn đoán xác định sớm các bệnh gan chuyển hoá không chỉ có ý nghĩa điều trị bệnh nhi mà còn giúp quản lý các biến chứng khi trẻ bước vào tuổi trưởng thành, tư vấn di truyền và phát hiện sớm những người mang bệnh thể ẩn. Nghiên cứu trong thời gian 2008-2019 tại Bệnh viện nhi trung ương cho thây bệnh gan chuyển hoá ở trẻ em khá đa dạng và có thể gây tổn thương gan dưới cả hai dạng cấp và mạn tính. Các nguyên nhân thường gặp ở trẻ nhỏ ghi nhận trong nghiên cứu này gồm thiếu hụt Citrin bẩm sinh 38,9\% bệnh Wilson 23,4\%, rối loạn chuyển hoá Glycogenose 13,5\%, Alagille 7,9\%, hội chứng PFIC, hội chứng ARC, AAT hiếm gặp hởn với các tỷ lệ lần lượt $2,9 \% ; 2,4 \%$ và $0,6 \%$. Nhóm RLCHK gồm các bệnh nhân Rotor; rối loạn chuyển hoá acid mật, Galactosemia, Tyrosinemia, DGOUK... mỗi bệnh chỉ phát hiện 1 bệnh nhân và 44 trường hợp có tổn thương gan kèm theo các triệu chứng của bệnh rối loạn chuyển hóa song không xác định được nguyên nhân gây bệnh $(10,4 \%)$

Các triệu chứng lâm sàng thường gặp nhất ở các trẻ có bệnh gan chuyển hóa gồm gan to $62,6 \%$, vàng da ứ mật $51.3 \%$, bất thường về 
hình thể $48.1 \%$ và rối loạn tiêu hóa $42.9 \%$. Một số triệu chứng lâm sàng ít gặp hơn như lách to, dị tật, chậm phát triển thể chất gặp ít hơn với tỳ lệ lần lượt $21,5 \% ; 20.9 \%$ và $21,9 \%$. các triệu chứng cận lâm sàng thường gặp gồm tăng bilirubin $55 \%$, rối loạn đông máu $57,1 \%$, giảm Albumin 43,5\%, tăng AST $82,6 \%$, tăng ALT $78,5 \%$. Môt số các xét nghiêm liên quan tới tình trạng rối loạn chuyển hóa cần lưu ý gồm tăng Lactac 43,3\%, tăng Cholesterol 35,6\%, Tăng Triglycerid 30,8\%, hạ Glucose $41,0 \%$, tăng NH3 $34 \%$ và tăng AFP $28,7 \%$

Việc tiếp cận trẻ em có bệnh gan chuyển hoá thường khó khăn. Ở trẻ sơ sinh, các triệu chứng ban đâuu của bênh dễ bị che lấp bởi các triệu chứng như nhiếm trùng, rối loạn thăng bằng toan kiềm, rối loạn đông máu và do diễn biến tính của bệnh. Vòng xoắn bệnh lý làm phát sinh các triệu chứng thứ phát, lấn át các triệu chứng cần chú ý như li bì bỏ bú, nôn trớ ở bệnh nhân Galactosemia, rối loạn đông máu sớm ở bệnh nhân Tyrosinemia, tằng lactat ở bệnh nhân có bệnh ti lạp thể...

Việc tiếp cận chẩn đoán ở trẻ lớn thường khó hơn ở những nhóm trẻ nhỏ và trẻ sơ sinh do bệnh thường chỉ thể hiện kiểu hình khi đã ở tình trạng mất bù khiến việc đánh giá phân tích kết quả xét nghiệm gặp khó khăn. Cần chú ý chẩn đoán bệnh gan chuyển hoá ở bệnh nhân có tổn thương gan cấp hoặc mạn tính sau khi loại trừ các nguyên nhân thường gặp như nhiễm trùng, ngộ độc, bệnh toàn thân... Đặc biệt chú ý bệnh gan chuyển hoá nếu bệnh nhân có các triệu chứng gợi ý tình trạng bệnh rối loạn chuyển hoá như bú kém, ngủ gà, co giật, giảm trương lực cơ, gan lách to, tổn thương đa cơ quan, có tiền sử gia đình...Các triệu chứng định hướng chẩn đoán khá quan trọng trong tiếp cận nguyên nhân gây bệnh ví dụ ở nhóm trẻ nhỏ có triệu chứng vàng da ứ mât: các bênh nhân NICCD thường có dấu hiệu Chubby face kèm tiêu chảy kéo dài phân mỡ; trẻ Alagille có khuôn mặt điển hình kèm theo tổn thương tim bẩm sinh, đốt sống hình cánh bướm, tổn thương thận; chứng ngứa khó kiểm soát, xanthomas trên da ở trẻ nhỏ kèm GGT bất thường ở bệnh nhân PFIC hay các trẻ có vàng da kèm co cứng khớp, khô da dạng vẩy cá, nhiểm toan ống thận... là các triệu chứng cần lưu ý để tiếp cận bệnh lý ARC...

Các bệnh nhân có triệu chứng gan to đơn thuần, hạ đường huyết khi đói và bộ mặt Doll face với hai má bầu bĩnh trên một trẻ cân nặng thấp cần lưu ý chẩn đoán Glycogenose bằng xét nghiệm sinh thiết gan chẩn đoán hoặc xét nghiệm gen. Tổn thương gan kèm theo triệu chứng gan lách to, tuần hoàn bàng hệ, cổ chướng có hoặc không kèm theo triệu chứng thần kinh cần lưu ý tới các nguyên nhân rối loạn chuyển hoá gây tổn thương gan mạn tính như Wilson, CTLN2, AAT... Trong nghiển cứu này chúng tôi gặp một số bệnh nhân thiếu hụt alpha 1 antitrypsin với triệu chứng vàng da ứ mật, tổn thương gan kèm theo tình trạng nhiễm khuẩn hô hấp tái diễn, tuy nhiên đây chỉ là nhận xét ban đầu do số lượng bệnh nhân AAT trong nghiên cứu này còn quá ít. Các bệnh ca bệnh Rotor, rối loạn chuyển hoá acid mật, Galactosemia, Tyrosinemia, DGOUK chỉ gặp mỗi trường hợp 1 bệnh nhân, bước đầu chỉ có thể ghi nhận các triệu chứng thường gặp ở các bệnh lý này

Trước các bệnh nhân nghi ngờ bệnh gan chuyển hoá, ngoài các xét nghiệm kiểm tra chức năng gan thông thường, các xét nghiệm tiếp cận chẩn đoán như khí máu, lactat, amoniac máu, đường máu khi đói, Cholesterol, Triglycerid, ceton máu, ceton niệu...rất có giá trị. Các xét nghiệm này thường thay đổi sớm hơn các xét nghiệm chức năng gan thông thường và sẽ giúp định hướng các bước chẩn đoán tiếp theo. Tuy nhiên, ngay cả khi những xét nghiệm này có giá trị bất thường thì chúng cũng không phải chỉ đặc hiệu cho một mình bệnh lý gan mà có thể gặp trong các bệnh như nhiễm trùng huyết, bệnh tim bẩm sinh, NH3.... Ngay cả một số các xét nghiệm khá đặc hiệu như Ceruloplasmin, đồng máu, đồng niệu 24h, định lượng Alpha 1 antitrypsin cũng bị ảnh hưởng bởi 1 số yếu tố gây sai số...Các xét nghiệm sàng lọc sau sinh như MSMS rất có ý nghĩa trong chẩn đoán sàng lọc các bệnh gan chuyển hoá và thường là cơ sở để tiến hành các bước xét nghiệm sau đó như acid hữu cơ niệu, acid amin máu...Trong đa số các bệnh gan chuyển hoá, xét nghiệm tìm đột biến gen gây bệnh là tiêu chuẩn vàng để chẩn đoán xác định.

Vàng da ứ mật do thiếu hụt citrin ở trẻ em (NICCD) là một trong những bệnh lý rối loạn chuyển hoá hiếm gặp, mới có khả năng tiếp cận trong khoảng 12 năm gần đây. Trong nghiên cứu này, NICCD chiếm $38,9 \%$ và là bệnh gan chuyển hoá được phát hiện nhiều nhất với tuổi chẩn đoán trung bình $3,2 \pm 1,6$ tháng. Bệnh gây vàng da ứ mật và suy gan ở trẻ nhỏ do đột biến trên gen SLC25A13 với các triệu chứng thường gặp gồm vàng da ứ mật $(81,7 \%)$, khuôn mặt Chubby face $(76,3 \%)$, tiêu chảy kéo dài phân mõ $(67,2 \%)$, suy chức năng gan với giảm Albumin $(73,1 \%)$ và $\operatorname{RLĐM}(88,2 \%)$, tăng $\operatorname{AFP}(67,2 \%)$ và $\mathrm{NH}(77,9 \%)$. Tỷ lệ bệnh nhân có chỉ số AST và 
ALT tăng lần lượt là $92,2 \%$ và $87,1 \%$. Các bênh nhân NICCD có thể được phát hiện sớm bằng xét nghiệm sàng lọc sau sinh và được chẩn đoán bằng xác định đột biến trên gen SLC25A13. Cần chú ý tới NICCD ở các trẻ vàng da ứ mât với khuôn mặt "Chubby face" có các triệu chứng suy gan, tiêu chảy kéo dài phân mõ̃, tăng AFP, tăng NH3 và tăng citrullin máu. Thành viên của các gia đình có trẻ NICCD cần được tư vấn để xét nghiệm sàng lọc để phát hiện sớm những người mang gen bệnh thể ẩn, vì khác thể NICCD có tiên lượng tốt sau điều trì, các bênh nhân người lớn mang đột biến SLC25A13 thường có kiểu hình suy gan tối cấp với tiên lượng nặng nề (thể CTLN2). Các bệnh nhân này nếu không được chẩn đoán xác định từ trước thường dễ bỏ sót chẩn đoán. Tình trang suy gan tối cấp ở các bệnh nhân CTLN2 sẽ tăng nặng nếu bệnh nhân được sử dụng các chế phẩm có đường và các thuốc có tính oxy hoá cao

Bệnh Wilson trước đây được nhắc nhiều tới ở nhóm bệnh nhân người lớn với các triệu chứng thần kinh hoặc bệnh gan mạn tính với các biến chứng nặng nề. Ngày nay, nhờ các tiến bộ trong di truyền, sinh hóa... chúng ta có thể phát hiện chẩn đoán và điều trị sớm các bệnh nhân Wilson từ thời kỳ tuổi nhỏ. Trong nghiên cứu này có 112 trường hợp Wilson chiếm tỷ lệ $23,4 \%$ với độ tuổi phát hiên trung bình $11 \pm 3,6$ tuổi, tập trung chủ yếu ở nhóm tuổi 5-15 tuổi. Các triệu chứng lâm sàng của bệnh nhân Wilson thường không điển hình, một số có triệu chứng gan to $(16,1 \%)$ lách to $(18,8 \%)$. Các triệu chứng cận lâm sàng thường gặp gồm giảm Ceruloplasmin $(97,3 \%)$, đồng niệu $24 \mathrm{~h}>0,1 \mathrm{mg} / 24 \mathrm{~h}(100 \%)$, tiêu cầu giảm $(67,2 \%)$, RLEM $(46,4 \%)$, giảm Albumin $(30,3 \%)$, tăng AST và ALT với các tỷ lệ lần lượt 48,2\%, 55,4\%. Đa số bệnh nhân Wilson được phát hiện trong nghiên cứu $(92,9 \%)$ đều là các bênh nhân có tổn thương gan mạn tính, chỉ có $8 / 112$ bệnh nhân Wilson $(7,1 \%)$ có triệu chứng vàng da ứ mật, song tất cả các bệnh nhân này đều có biểu hiện suy gan tối cấp với diễn biến nă̆ng và tử vong.

Cần chú ý chẩn đoán Wilson ở các bênh nhân có tăng Transaminase dai dẳng không rõ̃ nguyên nhân kèm theo các triệu chứng bệnh gan mạn tính như gan lách to, xuất huyết tiêu hoá, rối loạn đông máu, giảm tiểu cầu hoặc các trường hợp suy gan tối cấp kèm theo tan máu với test Coombs âm tính. Các xét nghiệm ban đầu giúp định hướng như Ceruloplasmin và đồng niệu 24h, khám mắt... rất có giá trị trong chẩn đoán ban đầu. Trong một số trường hợp, xét nghiệm phân tích tìm đột biễn trên gen ATP7B rất có ý nghĩa chẩn đoán xác định

Trong nhóm nghiên cứu có 64 bệnh nhân (chiếm tỷ lệ 13,4\%) được chẩn đoán xác định Glycogenose bắng tiêu chuẩn chẩn đoán mô bệnh học. Các bệnh nhân Glycogenose có các triệu chứng lâm sàng dễ nhận biết với gan to, triểu chứng hạ đường huyết khi đói, khuôn mặt điển hình. Các triệu chứng cận lâm sàng thường gặp ở bệnh nhân Glycogenose gồm tăng lactat máu $(64,1 \%)$ và tăng transaminase $100 \%$, tăng Cholesterol $(59,4 \%)$ và tăng Triglycerid $(65,6 \%)$

Hội chứng Alagille được phát hiện ở 38 bệnh nhân Alagille $(7,9 \%)$ với triệu chứng vàng da ứ mật kèm theo bộ mặt bất thường với đầu hình củ hành, trán cao và rộng, mắt sâu, sống mũi cao, tim bẩm sinh, cột sống bất thường và tổn thương thận... Chẩn đoán xác định thường dựa vào kiểu hình lâm sàng, tuy nhiên xét nghiệm phân tích các đột biến gây bệnh trên gen JAG1 và NOTCH2 không chỉ có ý nghĩa chẩn đoán xác định mà còn có ý nghĩa tư vấn di truyền.

Trong nghiên cứu phát hiện 4 bệnh nhân PFIC $(2,8 \%)$, các bệnh nhân này đều có đặc điểm vàng da ứ mật kéo dài, gan lách to. Cần lưu ý chẩn đoán hội chứng này nếu bệnh nhân vàng da ứ mật có chỉ số GGT tăng rất cao hoặc rất thấp so với Bilirubin, AFP tăng cao hoặc triệu chứng ngứa khó kiểm soát.

Hội chứng $A R C$ rất hiếm gặp với 12 bệnh nhân $(2,4 \%)$. Nếu lưu ý tới các triệu chứng điển hình cho bệnh như vàng da ứ mật, co cứng khớp, da khô dạng vẩy cá và nhiễm toan ống thận... có thể nhận biết các bệnh nhân ARC trên lâm sang.

Bệnh nhân AAT ở trẻ em hiếm gặp, trong nghiển cứu này chúng tôi chỉ gặp 3 bệnh nhân $(0,6 \%)$ với biểu hiện lâm sàng vàng da ứ mật kéo dài, tăng Transaminase ở mức độ trung bình dưới 200UI/L, định lượng alpha 1 antitrypsin cho thấy chỉ số này giảm dưới ngưỡng bình thường. Cả 3 bệnh nhân trong nhóm này đều có tình trạng nhiễm khuẩn hô hấp tái diễn song không có khí phế thũng. Tình trạng tổn thương gan tự giới hạn khi trẻ trên 12 tháng tuổi. Nhóm bệnh RLCK khác gồm 49 trường hợp $(10,4 \%)$ trong đó Rotor, rối loạn chuyển hoá acid mật, Galactosemia, Tyrosinemia, DGOUK mỗi trường hợp có 1 bệnh nhân, 44 trường hợp khác có bệnh lý gan kèm theo các bằng chứng của rối loạn chuyển hoá như vàng da ứ mật, suy gan, gan lách to, tổn thương đa cơ quan kèm theo các dấu hiệu gợi ý tới tình trạng rối loạn chuyển hoá như tăng lactat, nhiễm toan chuyển hoá, ha đường huyêtt, tăng Cholesterol, Triglycerid và 
AFP... song không phân loại được nguyên nhân gây bệnh.

\section{KẾT LUẬN}

Các bệnh gan chuyển hóa là các nguyên nhân có thể gầy tồn thương gan dưới cả hai dạng cấp tính và mạn tính. Bệnh không chỉ gây ảnh hưởng tới các trẻ bị bệnh trong thời kỳ thơ ấu mà còn gây hậu quả ở tuổi trưởng thành. Các bệnh gan chuyển hoá có những kiểu hình khá đa dạng như bệnh gan mạn ở các bệnh nhân Wilson, NICCD, Glycogenose, PFIC, Alagille...hay cấp tính với hậu quả nặng nề như suy gan tối cấp ở bệnh nhẩn Wilson, CTLN2... Việc chẩn đoán xác định các bệnh nhân có bệnh gan chuyển hoá không chỉ có ý nghĩa điều trị và cứu sống bệnh nhi ở tuổi thơ ấu mà còn giúp quản lý tình trạng bệnh, kiểm soát triệu chứng, biến chứng của bệnh đảm bảo ổn định chất lượng cuộc sống của bệnh nhân không chỉ trong thời kỳ̀ thơ ấu mà cả ở tuổi trưởng thành.
TÀl LIỆ THAM KHẢO

1. Kaur S, Kumar P, Kumar V, Sarin SK, Kumar A. Etiology and prognostic factors of acute liver failure in children. Indian Pediatr. 2013 vol 50 pages 677-689

2. Khanna $\mathbf{R}$, Alam $\mathbf{S}$, Sherwani $\mathbf{R}$, Arora $\mathbf{S}$, Arora NK, Malik A. Alpha-1 antitrypsin deficiency among Indian children with liver disorders. Indian J Gastroenterol. 2006; vol 25 pages191-193

3. Zhang $\mathbf{Z H}$, Lin $\mathbf{W X}$, Deng $\mathbf{M}$, et al. Clinical, molecular and func- tional investigation on an infant with neonatal intrahepatic cholestasis caused by citrin deficiency (NICCD). PLoS One. 2014 vol 9 pages 89267

4. European Association for Study of Liver. EASL clinical practice guidelines: Wilson's disease. J Hepatol. 2012 Vol 56 pages 671-685.

5. Arora NK, Arora S, Ahuja A, et al. Alpha 1 antitrypsin deficiency in children with chronic liver disease in North India. Indian Pediatr. 2010 vol 47, pages 1015-1023.

6. Keli Hansen, Simon Horslen et al. Metabolic liver disease in children (2008). Liver transplantation Vol 14, pages 713-733

\section{ĐĂC ĐIỂM LÂM SÀNG, CÂN LÂM SÀNG VÀ MộT Số YẾU Tố LIÊN QUAN ĐẾN KẾT QUẢ ĐIỀU TRI BỆNH NHÂN SỐC NHIỄM KHUẨN TẠI BÊ̂NH VIỆN TRUNG ƯO'NG THÁI NGUYÊN}

\section{TÓM TẮT}

Mục tiêu: Mô tả đặc điểm lâm sàng, cận lâm sàng và phẩn tích một số yểu tố liên quan đến kết quả điều trị bệnh nhân sốc nhiê̂m khuẩn. Đối tượng, phương pháp nghiên cứu: Nghiên cứu mô tả cắt ngang trên 47 bệnh nhânsốc nhiểm khuẩn. Kết quả: Tuổi trung bình của đối tượng nghiên cứu là $61,4 \pm 15,2$. Tuổi cao nhất là 92 và tuổi thấp nhất là 15 . Giới tính nam chiếm tỷ lệ cao hơn 76,6\%, nữ chỉ chiếm 23,4\%.Đa phần các bệnh nhân sốc nhiễm khuẩn có không có sốt hoặc sốt nhè. Sốt cao chỉ chiếm 23,4\%, trong khi đó tỉ lệ bệnh nhẩn không sốt chiếm cao nhất tới $61,7 \%$. Vị trí ổ nhiễm khuẩn tiên phát thường gặp chủ yếu là cơ quan hô hấp và tiêu hóa, trong đó hô hấp chiếm $44,7 \%$, tiêu hóa là $34 \%$. Kết quả nuôi cây vi khuẩn chỉ cho kết quả dương tính $17 \%$. Gía tri trung bình lactat máu của bệnh nhân sốc nhiếm khuẩn là $6,82 \pm 4,16$. Đa số bểnh nhân có gái trị lactat máu $>6 \mathrm{mmol} / \mathrm{l}$ chiếm tỉ lê $51,1 \%$. Có mối liên quan có ý nghĩa thống kê với đổ tin cậy $95 \%$ giữa tình trạng rối loạn đông máu, thở

${ }^{1}$ Trường Đại học Y dược Thái Nguyên

²Bệnh viện Trung ương Thái Nguyên

Chịu trách nhiệm chính: Nguyễn Thanh Thủy

Email: thanhthuyyk44@gmail.com

Ngày nhận bài: 21.10.2020

Ngày phản biên khoa hoc: 23.11.2020

Ngày duyệt bài: 8.12 .2020

\section{Nguyễn Thanh Thủy ${ }^{1}$, Phạm Kim Liên ${ }^{1,2}$}

máx xâm nhập và kết cục ra viện ở bệnh nhân sốc nhiếm khuẩn. Kết luận: Bệnh nhân tuổi càng cao càng có nguy cơ sốc nhiê̂m k̉huẩn cao hơn. Nam giới có tỉ lệ mắc bệnh cao hơn nữ giới. Ổ nhiễm khuẩn tiên phát thường gặp nhất là cơ quan hô hấp, tỉ lệ cây máu dương tính thấp. Có mối liên quan có ý nghĩa thống kê với độ tin cậy $95 \%$ giữa tình trạng rối loạn đông máu, thở máy xâm nhập và kết cục ra viện ở bệnh nhân sốc nhiễm khuẩn.

Ti̛ khóa: Lâm sàng, cận lâm sàng, yếu tố liên quan, sốc nhiễm khuẩn.

\section{SUMMARY \\ CLINICAL, SUBCLINICAL \\ CHARACTERISTICS ANH SOME FACTORS RELATE TO TREATMENT OUTCOME IN PATIENTS WITH SEPTIC SHOCK}

Objective: Describe clinical, subclinical characteristics and analysis some factors relate to treatment outcome in patients with septic shock. Methods: The descriptive study cut across 47 patients in septic shock. Results: Average age of study subjects is $61,4 \pm 15,2$. The highest age is 92 and the lowest one is 15 . Male sex accounts for $76,6 \%$ higher rate, female only $23,4 \%$. The majority of patients with septic shock have no fever or mild fever. High fever only accounted for $23,4 \%$, while the proportion of patients without fever was the highest at $61.7 \%$. Common primary sites of infection are 